\title{
Village Fund Accountability in Kecamatan Padang Batung (Study on the Development of Farming Business Road Infrastructure in Pendulangan Village)
}

\author{
Heri Utomo $^{1 *}$, Andi Tenri Sompa ${ }^{1}$, Ahmad Yunani ${ }^{1}$ \\ ${ }^{1}$ Masters in Development Administration, Postgraduate Program, Lambung Mangkurat University, Banjarmasin, Indonesia
}

DOI: $10.36348 /$ sjef.2021.v05i02.011 $\quad$ | Received: 09.02.2021 | Accepted: 23.02.2021 | Published: 26.02 .2021

*Corresponding author: Heri Utomo

\section{Abstract}

The distribution of Village Funds (VF) is as stimulant assistance or stimulant funds to encourage the financing of Village Government programs supported by community self-help cooperation in carrying out government activities and community empowerment. This study aims to describe the accountability of the development of the Farm Business Road (FBR) from planning, implementation and accountability, research using qualitative descriptive methods. The data collection method in this research is through Participatory Rural Appraisal (PRA). The research data was obtained through several data collection methods in PRA such as transect walks, interviews with several informants and supporting documents including village development budget documents and reports on the realization of the use of the Pandulangan village budget. The results of this research can be concluded that the development of FBR is accountable, transparent in planning, transparent in implementation and can be accounted for by the rules. The development of FBR has a positive impact on the community, including easy access and savings in the cost of transporting agricultural products.

Keywords: Village Fund, Accountability, Project Management, FBR of Pandulanganan Village.

Copyright $\odot$ 2021 The Author(s): This is an open-access article distributed under the terms of the Creative Commons Attribution 4.0 International
License (CC BY-NC 4.0) which permits unrestricted use, distribution, and reproduction in any medium for non-commercial use provided the original
author and source are credited.
author and source are credited.

\section{INTRODUCTION}

The government and the people of Indonesia are currently in an effort to improve development, aiming to achieve national ideals and goals, namely to create a fair and prosperous society that is equitable based on Pancasila and the 1945 Constitution. through the implementation of road development programs which are the most dominant transportation network used by residents for activities. Based on the law of the Republic of Indonesia Number 6 of 2014 concerning Villages, it is stated that villages have rights of origin and traditional rights in regulating and managing the interests of the local community and play a role in realizing the ideals of Village independence, or other designations that are very diverse in Indonesia, Initially it was a local community organization which had territorial boundaries, was inhabited by a number of residents, and had customs to manage itself.

Roads are the most important access for both economic and development activities. The connecting route between villages and cities is a means of mobility to carry out various transaction processes which result in a better development process. In the economic context, roads as the social capital of the community are the base of economic development, so that high economic growth is difficult to achieve without adequate road availability. Various programs also emerge every year, both from the central government and regional governments, which aim to encourage development progress and improve the welfare of the community, especially rural communities, through the Village Fund.

The purpose of providing the Village Fund (VF) is as stimulant assistance or stimulant funds to encourage the financing of Village Government programs supported by community self-help participation in carrying out government activities and community empowerment, besides that the Village Fund is a form of state recognition to villages to fund needs villages in the context of administering governance and implementing development and community services where the village is placed as the basis for decentralization. 
Heri Utomo et al., Saudi J Econ Fin, Feb, 2021; 5(2): $95-99$

Padang Batung District is one of 11 subdistricts in Hulu Sungai Selatan Regency. which has 17 villages. The Village Fund allocation from the central government for 2019 amounts to Rp. 13,307,959,000,with an average of around Rp. 782,821,118 per village, while the average budget was $91 \%$. The construction of 4 farm roads (JUT) in Pandulangan village, spread over 4 RTs with a total budget allocation of Rp. 421,692,600 or $54 \%$ of the total Village Fund budget as a whole. However, in its implementation there is a difference between the budget and the realization of one of the developments, namely Jalan Tani Darmi, there is a budget difference of Rp. 6,390,000,-. Based on these data, a research on the accountability of the infrastructure development for the Farm Roads was carried out through village funds in the Pandulangan Village, Padang Batung District.

\section{METHOD}

This research is a descriptive study with a qualitative approach. Data collection was carried out by observation and interviews. Observations in the field were the construction of Farmers' Roads in the Pandulangan Village. Interviews were conducted by asking questions directly to respondents. Semistructured interview model (semi-structured interview) in an interview where the interview is conducted by first preparing questions and alternative answers but in practice it is more open and free where the respondent is asked for opinions or ideas and the interviewer records or records what the respondent says. The unit of analysis in this research is the report on the financial realization of the Village Fund, the Profile of the Village of Pandulangan, Padang Batung Subdistrict in 2019. The researcher made this unit of analysis with the consideration of knowing the accountability of village funds. Data analysis in this study used the Participatory Rural Appraisal (PRA) technique. In the opinion of Chambers [4], PRA is a method used to understand villages in a participatory manner by reflecting the development of a group of approaches and methods that allow village communities to share, add and analyze knowledge about living conditions in order to make plans and actions.

\section{RESULTS AND DISCUSSION}

\section{Accountability of Farmer Business Roads}

Sulistiyani [1] states that transparency and accountability are two key words in good governance and corporate governance, it is also stated that accountability contains the obligation to present and report all activities, especially in the field of financial administration, to higher parties. According to Mardiasmo [2], there are three main principles that underlie regional financial management:

1) The principle of transparency or openness. Transparency here means that members of the public have the same rights and access to know the budget process because it involves the aspirations and interests of the community, especially the fulfillment of the people's daily needs.

2) The principle of accountability. Accountability is the principle of public responsibility, which means that the budgeting process, starting from planning, preparation and implementation, must actually be reported and accountable to BPD and the public. The public not only has the right to know the budget but also the right to hold accountable for the planning or implementation of the budget.

3) The principle of value for money. This principle means the application of three main points in the budgeting process, namely economical, efficient, and effective. Economics is concerned with the selection and use of resources in a certain quantity and quality at a low price. Efficiency means that the use of these public funds can produce maximum output (efficient). Effectiveness means that the use of the budget must achieve targets or objectives of the public interest.

\section{a. Planning transparency}

The purpose of implementing development in the village is to empower village communities which can further improve the economy of the village community itself. The success of an activity project cannot be separated from the pros and cons of an activity plan. Good planning must involve various related parties to add input and suggestions in order to maximize the quality of project activities carried out later.

"Planning, implementing and evaluating the Village Fund budget in our village have met the stages regulated by the applicable regulations, starting from the proposal for RT, village development planning meetings, Village RKP and implementation to the realization report, we submit it through an announcement (billboard) in the village office yard."

In 2019 the use of village funds is regulated by the Regulation of the Minister of Villages, Development of Disadvantaged Areas and Transmigration Number 16 of 2018, so that the determination of activities to be carried out in 2019 must pay attention to the priority scale set out in the regulation.

According to information from the village head, all development planning has followed the prevailing regulations, and has conducted pritority screening at the household level by means of a push, when taken to the village musrenbang. Development planning also involves the community or community leaders. This is supported by information from one of the farmer communities whom the author interviewed.

"The village government of Pandulangan always involves community leaders in every development plan; usually musrenbang is combined with the preparation of development plans Village" 
Heri Utomo et al., Saudi J Econ Fin, Feb, 2021; 5(2): $95-99$

In the 2019 fiscal year, the Pandulangan Village government plans several activities budgeted through the Village Fund, including:

1) MANDARAHAN Farmer's business road, is a Farmer business road proposed by the residents of the Pandulangan community in the RT.01 area with a budget amount of Rp. 179,950,000,-with a length of $500 \mathrm{~m}$ and a width of $2 \mathrm{~m}$.

2) TIA Farmers Road, is a farming road proposed by residents of the Pandulangan community in the RT.02 area with a budget of Rp. 87, 700, 600,- with a length of $268 \mathrm{~m}$ and a width of $2 \mathrm{~m}$.

3) ANGLAI Farmer Road, is a farming road proposed by the residents of the Pandulangan community in the RT.03 area with a budget of Rp. 76, 495, 000,$778 \mathrm{~m}$ long and $2 \mathrm{~m}$ wide.

4) DARMI Farmers Road, is a farming road proposed by residents of the Pandulangan community in the RT.04 area with a budget of Rp.77,470,000 with a length of $778 \mathrm{~m}$ and a width of $2 \mathrm{~m}$.

It can be seen that the use of the JUT budget can be realized, there is only one JUT that has a SILPA, namely JUT DARMI. According to the information provided by the TPK, accompanied by the planning and financial affairs division, there was a planning difference in the RAB.

"For JUT Darmi, there is Silpa, which means that the excess funds are around 6 million, due to planning errors in determining the unit price of goods that exceeds the regency unit price, so the budget is excessive"

This was also confirmed by the village head, that there was a lack of information from the planning consultant in inputting the Darmi farm road planning budget.

The principle of transparency is also called openness. Transparency here means that members of the public have the same rights and access to know the budget process because it involves the aspirations and interests of the community, especially the fulfillment of the people's daily needs. Infrastructure development is one of the priorities mandated by the Minister of Home Affairs regulation in accelerating the use of Village Funds. The construction of a farm road in Pandulangan Village is a manifestation of the implementation of the Development Sector that has been planned through the Village Budget which is sourced from the Village Fund.

Financial accountability according to Mardiasmo is openness or transparency, and is accountable or accountable. According to information from the Head of Pandulangan Village, Mr. Suriani, development planning in Pandulangan Village began with a consultation at the RT level, then the results of the meeting were conveyed at the Village Level
Development Planning Conference (Musrenbang Desa). In this deliberation activity each RT representative will submit proposals and requirements that will be compiled in the Village Development Work Plan (RKP Desa).

From the statement of the village head, it can also be seen that the transparency of the use of Village Funds has also been implemented, this is evidenced by the announcement through printed media (billboards) placed on the page of the Pandulangan Village office, so that information regarding the Village fund budget can be accessed by the public. In terms of planning transparency, village government officials have provided information to the community about what activities will be carried out with funds from AVF or VF. this is a shared learning to implement good governance. The principle of transparency is upheld by the implementers of the VF program in Pandulangan Village so that it is expected to get feedback/community responses in improving development performance. This is in accordance with the concept of transparency [3], which can be known by many interested parties regarding the formulation of (political) policies from the government, organizations, and business entities.

In addition, the provision of information is carried out openly against criticism that is seen as participation in making improvements, from planning to post-development activities, the form of transparency carried out by the Pandulangan village government is to use the information board media. In every farm road construction project, a project information board is displayed, where on the information board the community can find out the amount of the budget implemented, the length and width of the road that was built, and the length of time it was carried out and what kind of work was done.

In the 2019 budget year, the Pandulangan Village government has carried out several activities budgeted through the Village Fund, including:

1) MANDARAHAN Farmer's business route

2) TIA Farmer's business path

3) ANGLAI Farmer's business road

4) DARMI Farmer's business path

\section{b. Transparency of Implementation}

After a series of planning carried out by the Pandulangan village government, the next agenda is the activity of scheduling implementation activities, the activities that have been determined by the Pandulangan Village Government are stipulated in the APBDesa document for the 2019 Fiscal Year.

The preparation of an activity agenda must of course take into account various factors, including the weather or the erratic rainy season; this will affect the implementation of activities that have been scheduled. According to information obtained from the village 
Heri Utomo et al., Saudi J Econ Fin, Feb, 2021; 5(2): $95-99$

head, physical development activities are not specifically scheduled, and are only based on the current fiscal year. Regarding the activities that have been planned, sometimes not all activities can be realized. According to information from the Activity management team.

"Not all physical activities or other activities can be carried out fully, considering that due to natural conditions, or from an inadequate or insufficient budget, sometimes there is also a policy from the district government which becomes a priority that must be aligned with village policies.

With the conditions presented by the TPK, it can be seen that and it can be concluded that development activities cannot run effectively, this can also be known through the realization of the Village budget.

Implementation is the most important part in an activity or program implementation, in Pandulangan Village, in managing VF, a team was formed to carry out and manage activities financed by VF, namely the Activity Management Team (TPK). The TPK is chaired by the village apparatus (the Head of Services and Welfare). The TPK is directly elected by the Village Head and legalized through a Village Head Decree concerning TPK for JUT activities. TPK has duties in the field while the treasurer is in charge of working on administrative affairs. The implementation begins with a fund disbursement process carried out by the village treasurer at a predetermined bank, after the disbursement process the parties and partners are invited to agree on the activities to be financed.

The implementation of the construction of farm roads in Pandulangan Village implements the principles of openness and participation from the community. The form of openness is to involve the community in the development location as a member of the Activity Management Team. The participation of community representatives is not only as members of the TPK, but also laborers and masons who work from the construction site. In addition, it is also intended to provide convenience in communication with community members who own the land or agricultural land on which the farm road will be built. Prior to implementation, there must be an agreement in the form of a grant agreement made between the land owner and the village government, accompanied by a statement letter with dimensions.

The problem that occurs during the construction implementation is the unpredictable weather conditions, so that the development tends to be late from the scheduled schedule, although it is specifically not presented in the implementation document. Other obstacles faced are the limited building materials and the distance to make the farm road quite far from the main road. c. Accountability

In the implementation of development, the role of the TPK greatly influences the work carried out, the TPK manages all the completeness of the files from the start of the budget planning (RAB) to the completion of the activity. Controlling the development of the Farmer's business road involves the surrounding community. This is evidenced by the results of the author's interviews with farmers.

"Directly or indirectly, we can see the development of farm road construction, because our business is farming and gardening, so indirectly we can see the road developments being carried out by the village government every day"

Apart from community elements, the village head also plays a role in controlling the construction of farm roads as well, the village head is a budget user who is responsible for the expenditure of Village funds which are channeled to the activity management team.

"We always monitor development developments in the village, not only farm roads but also other developments, because it is my responsibility as the village head to ensure that development can be completed"

The role of the community apart from JUT users also participates in the control of development in Pandulangan, this is evidenced by reports from community members to the TPK about jobs that are not neat or not in accordance with standards. So that this report becomes material for evaluation by the TPK in completing work. This report is also submitted by the community to the village head and sub-district government.

From the information obtained from the TPK, the work was indeed in progress and had not been fully completed.

"The Minister of Religion has once complained from the community to the Village Head and District Government (Kasi Government) that there is work that has not been completed and the physical building is not in accordance with the RAB.

From the information above, it can be seen that the role and participation of the community in the supervision and control of the development of the Farm Business Road is quite high, this is evidenced by the criticism and reports directly to the village head and sub-district government so that this will have a good impact on development development in the field.

Based on information from agricultural extension workers on the impact of JUT development, it contributes positively to the ease of access in and out of agricultural products, with this easy access will economically reduce the wages for transporting 
Heri Utomo et al., Saudi J Econ Fin, Feb, 2021; 5(2): $95-99$

agricultural products. This was confirmed by the communities I interviewed with.

"With the existence of JUT, we are grateful, the road to rice fields and gardens is easier and faster, and the wages for transporting unhulled rice after harvesting there are also savings of around Rp. 3000 to Rp. 5,000 per bag. With an estimated agricultural yield of Rp. 440,000/ha."

From the results of these interviews it can be concluded that the impact of JUT development has had a positive impact on the community's economy, although it is not too significant for agricultural output.

Accountability Tjokroamidjojo [3] is the accountability of the management/ implementation that is carried out. If this is related to the implementation of the level of participation of the village community through the implementation of the VF program in the Village of Pandulangan, the principle of accountability/responsibility has gradually begun to be applied even though it is not yet perfect, but has shown a very strong commitment to carry out responsibilities in accordance with their capacity and position.

Reporting is a form of accountability carried out by the village government, especially in the management of this VF. In Pandulangan village, the reporting system was carried out in two forms, namely substantive and normative. Substantially, the village government reports every 3-4 months, namely through deliberations conducted by the village government with the BPD and LPM. This reporting will facilitate the evaluation process for the implementation of programs or activities financed by VF. Whereas normatively the village government is obliged to report every activity or program financed by AVF or VF by making an SPJ report to the Regency with approval and passing through the District. The report contains a list of planned programs or activities that are realized, to documentary evidence.

Responsibility for the construction of a farmowned business road is integrated with the accountability for the APBDes. This is in accordance with Hulu Sungai Selatan Regent Regulation Number 19 of 2015 concerning Guidelines for Village Financial Management in Hulu Sungai Selatan District.

The Regent Regulation is intended to provide a legal basis for village finance, village financial sources, village financial management, and village income and expenditure budgets so that they can be accounted for in an accountable manner. Strengthening village finance is carried out to strengthen the pillars of transparency and accountability. Village financial management must be carried out efficiently and effectively, transparently and accountably. The Village Fund, which is one of the main sources of village income, must also be accounted for in a transparent manner to the community and to the upper level government as an institution that gives authority to the Pandulangan Village government.

Internal and external accountability to the community has been carried out periodically every year at least once through regular inspections from the inspectorate and periodically by the sub-district government assisted by Village assistants (P3MD).

In order to ensure the openness of VF management, P3MD assistants always make corrections and checks in every request for withdrawal or fund withdrawal plans as one of the requirements for getting recommendations from the sub-district head, this is also the responsibility of the Village in completing Village financial administration. The camat's recommendation is used as the basis for the accountability and control of the banking sector in channeling funds from the Village Treasury to the Village Treasurer.

\section{CONCLUSSION}

The accountability of village funds for the development of farm road infrastructure in the Padang Batung sub-district is accountable and accountable. Transparency The planning of the four farm business roads in Pandulangan village had applied the principles of accountable and transparent financial management. However, it was found that the TPK and planning consultants had a lack of knowledge in determining the unit price at JUT Darmi, resulting in a remaining budget. The implementation of the four-road farming program in Pandulangan Village has technically implemented community participation, so that its implementation can be directly monitored, either by the village head or from the community directly.

\section{SUGGESTION}

In order to achieve the maximum target in the accountability of the use of Village Funds to midwives for the development of road infrastructure for farming, active supervision from Village Facilitators (P3MD) can be carried out in determining the RAB and adjusting the unit price volume so that there is no longer any reason for ignorance of the unit price.

\section{REFERENCE}

1. Teguh, A. (2004). Kemitraan dan model-model Pemberdayaan. Yogyakarta: Gava Media, 2.

2. Mardiasmo. (2002). Otonomi Daerah dan Manajemen Keuangan Daerah, Andi, Yogyakarta.

3. Tjokroamidjojo, B. (2000). Good governance. Paradigma Baru Manajemen Pembangunan. Jakarta: UI press.

4. Chambers, R. (1992). PRA-Participatory Rural Appraisal-Memahami Desa Secara Partisipatif. Yogyakarta. Kanisius. 